\title{
Impact of war on veteran life span: natural experiment involving combat versus non-combat exposed military personnel
}

\author{
Nick Wilson (1) , ${ }^{1}$ C Clement, ${ }^{2}$ J A Summers, ${ }^{1}$ G Thomson, ${ }^{1}$ G Harper ${ }^{1}$
}

\begin{abstract}
- Additional supplemental material is published online only. To view, please visit the journal online (http://dx.doi. org/10.1136/bmjmilitary-2021 001991)
\end{abstract}

1 Department of Public Health, University of Otago Wellington, Wellington, New Zealand ${ }^{2}$ Independent researcher, Te Puke, New Zealand

\section{Correspondence to} Professor Nick Wilson, Public Health, University of Otago Wellington, Wellington, New Zealand; nick.wilson@otago. ac.nz

Received 4 September 2021 Accepted 18 November 2021

Check for updates

(c) Author(s) (or their employer(s)) 2021. No commercial re-use. See rights and permissions. Published by BMJ.

To cite: Wilson $\mathrm{N}$, Clement $\mathrm{C}$ Summers JA, et al.

BMJ Mil Health Epub ahead of print: [please include Day Month Year]. doi:10.1136/ bmimilitary-2021-001991

\section{ABSTRACT}

Introduction There is still uncertainty around the impact of combat exposure on the life span of war veterans. Therefore we made use of a natural experiment to study the impact on veteran life span of combat versus noncombat exposure in World War II (WW2).

Methods The combat-exposed military personnel were derived from a random (10\%) sample of the military roll of the 28th (Māori) Battalion from New Zealand. One non-combat cohort was the 15th Reinforcements of this same Battalion, since the war ended before they reached the front line. The other non-combat cohort were Māori personnel who were only involved in Jayforce, which occupied Japan at the end of the WW2. Data on life span were mainly derived from an official repository of birth and death records, but supplemented with other sources, including military files.

Results When comparing life spans of service veterans, there was no statistically significant reduction for the average life span of the 234 combat-exposed veterans in our sample from the 28th (Māori) Battalion (66.7 years), relative to the Māori veterans from two non-combat cohorts: the 132 personnel in the 15th Reinforcements (67.2 years) and the 147 personnel in Jayforce (66.9 years).

Conclusions Despite a very high level of wounding in the combat-exposed group (48\%), there were no statistically significant reductions in life span between this group and comparable non-combat exposed veterans. This finding contrasts to life span reductions found in a similar study of New Zealand veterans of WW1.

\section{INTRODUCTION}

It is important to understand both the short-term and long-term health impacts of war, given ongoing conflicts around the world that can harm both civilians and military personnel. Various studies provide evidence of long-term harm to health among war veterans. $^{12}$ Nevertheless, an increase in all-cause mortality in war veterans has not always been identified. ${ }^{3}$ Furthermore, studying the issue of veteran life span is complicated by the 'healthy soldier effect' which is a type of selection effect analogous to the 'bealthy worker effect'. ${ }^{4}$ In addition there can be another selection effect in the form of the 'healthy warrior effect', whereby healthier personnel within the military are the ones involved in combat (relative to those away from the front lines). ${ }^{4}$

Given this background, we considered a 'natural experiment' relating to New Zealand military personnel involved in World War II (WW2). That

\section{Key messages}

There is still uncertainty around the impact of combat exposure on the life span of war veterans.

- This study compared the life spans of World War II veterans with and without combat exposure.

- It found that there was no statistically significant reduction for the average life span associated with combat exposure.

- That is, the mean life span of the combat exposed veterans was 66.7 years versus from two non-combat exposed cohorts at 67.2 years and 66.9 years.

- This finding contrasts to life span reductions found in a similar study of New Zealand veterans of World War I.

is, we were able to compare groups of military personnel who had either combat exposure or no combat exposure. Specifically, the men in the 28th (Māori) Battalion up to and including the 14th Reinforcements had combat exposure, while the 15 th Reinforcements for this Battalion who left New Zealand in a troopship did not reach Egypt until May 1945, by which time the war in Europe had ended. Similarly, another comparable non-combat group arose via the Māori military personnel sent to participate in the occupation of Japan (Jayforce), with embarkations from 1 January 1946 to 30 June $1948 .^{5}$

The 28th (Māori) Battalion was part of the second New Zealand Division, the fighting arm of the Second New Zealand Expeditionary Force (2NZEF) during WW2. ${ }^{6}$ It was a front-line infantry unit made up entirely of volunteers. It usually contained 700-750 men, divided into five companies. It fought in battlefields in Greece, Crete, North Africa and Italy. In the words of Lieutenant-General Bernard Freyberg (who commanded the second New Zealand Division), 'no infantry battalion had a more distinguished record, or saw more fighting, or, alas, had such heavy casualties as the Maori Battalion'. The last Māori recruits to see action, part of 2NZEF's 14th Reinforcements, arrived in Italy in April 1945. Multiple publications provide extensive details on the Battalion ${ }^{7}$ and its specific companies. ${ }^{89}$ 


\section{METHODS}

\section{Combat-exposed cohort}

For the combat-exposed cohort, we used an online data set of the personnel of the 28th (Māori) Battalion. ${ }^{10}$ This dataset was comprised of all those who served in the Battalion up to and including the 14th Reinforcements, including those who were 'killed on active service' in New Zealand after combat service overseas. From this data set we obtained a $10 \%$ random sample $(n=340$ individuals out of 3402 on the online roll), using random numbers generated in Excel. Of note is that this online roll was apparently still not quite complete, as the total who served in the Battalion was estimated at $3600 .{ }^{10}$ To maximise comparability with the other studied cohorts of Māori personnel (see below), we excluded from the final sample personnel of identifiable nonMāori ethnicity. That is, five personnel were excluded: three from the Pacific Islands (eg, Cook Islands and Niue) and two officers of known European ethnicity.

\section{Non-combat exposed cohort, 28th (Māori) Battalion reinforcements}

For the first non-combat exposed cohort, we used a list of the 15th Reinforcements of the 28th (Māori) Battalion (all 152 personnel, ${ }^{11}$ none of whom were known to be non-Māori). This group did not reach Egypt from New Zealand until May 1945, after the war in Europe ended. They spent some time in Italy before many became part of the occupying forces in Japan (ie, 'Jayforce'). From this group we removed all those who had any evidence of prior or subsequent involvement in a war (ie, including WW1, WW2, Vietnam, Korea and Malaya). This resulted in the exclusion of 10 personnel, all of whom had evidence of prior participation in WW2, to give a final sample of 142 .

\section{Non-combat exposed cohort (Māori soldiers in Jayforce)}

The second non-combat cohort were Māori personnel who participated only in Jayforce, that is, the 16th and subsequent Reinforcements who travelled directly from New Zealand to occupied Japan. For assembling this cohort, we selected all Jayforce personnel in the Cenotaph database ( $n=1152$ names) and removed those who: (1) Had participated in any war (including WW1, WW2, Vietnam, Korea and Malaya); (2) Had female first names (given our focus on just comparing male life spans); (3) Who were in a service other than the army; and (4) Did not have any Māori names (ie, names in te reo Māori) or were from the Pacific Islands (eg, next of kin had an address in the Cook Islands). This resulted in a final sample of 171 personnel.

Analyses by name and serial number were conducted to ensure that all the three cohorts contained no duplicate individuals.

\section{Life span data}

We collected data on birth dates, death dates and any reported age at death, based on the following sequence of steps:

1. We searched for details on the online 28th (Māori) Battalion roll. ${ }^{10}$ This roll also helped provide alternative names used by the individuals, which assisted with subsequent searches. It also provided prisoner-of-war (POW) status.

2. The Births Deaths and Marriages database was then searched. It contains records of all New Zealand-based deaths covering the relevant time period. ${ }^{12}$ It was however, incomplete for Māori births since registration of Māori births only became a legal requirement in March 1913 (although this would only have applied to a small proportion of these cohorts given the birth years detailed in Table 1).

3. The Cenotaph website database ${ }^{13}$ was then searched. It occasionally had additional birth/death/age data, alternative names used, and also POW status.

4. Searches were then conducted of genealogical databases (eg, cemetery records) and also the 'Last Post' publication compiled by the Royal New Zealand Returned and Services Association.

5. Finally we obtained assistance from New Zealand Defence Force personnel who examined personal military records to identify missing dates of birth and death.

In some cases, only the birth year or year of death could be identified, so we used the midyear point of such years (eg, 1 July) in the analyses to calculate the age at death. Also when the reported age at death was recorded in years only, we used a midpoint value, that is, age '70 years' was adjusted to '70.5 years'.

Table 1 Characteristics of the combat-exposed cohort (28th (Māori) Battalion) and the two non-combat exposed cohorts (the 15th (Māori) Reinforcements; Māori personnel in Jayforce) of New Zealand military personnel

\begin{tabular}{|c|c|c|c|}
\hline Characteristic & $\begin{array}{l}\text { Random } 10 \% \text { sample } 28 \text { th (Māori) } \\
\text { Battalion personnel } \\
(\mathrm{n}=335)\end{array}$ & $\begin{array}{l}\text { 15th Reinforcements; 28th } \\
\text { (Māori) Battalion (non-combat) } \\
\text { (n=142) }\end{array}$ & $\begin{array}{l}\text { Māori personnel in Jayforce (non- } \\
\text { combat) }(n=171)\end{array}$ \\
\hline $\begin{array}{l}\text { Any name in te reo Māori (including 'also known as' } \\
\text { names considered) (\%) }\end{array}$ & $76.7 \%$ & $73.9 \%$ & $100 \%$ (by definition of this cohort) \\
\hline Private or trooper (\%) & $81.4 \%$ & $90.9 \%$ & Not readily available \\
\hline Officer (\%) & $18.6 \%$ & $9.2 \%$ & Not readily available \\
\hline Prisoner of war (POW) (\%) & $3.6 \%(12 / 335)$ & Not applicable & Not applicable \\
\hline Median year of birth where known (IQR) & $\begin{array}{l}1918 \\
\text { (1914 to 1921) }\end{array}$ & $\begin{array}{l}1923 \\
\text { (1922 to } 1925.5)\end{array}$ & $\begin{array}{l}1926 \\
\text { (1924 to 1927) }\end{array}$ \\
\hline $\begin{array}{l}\text { Age at death could not be calculated (ie, missing dates } \\
\text { of birth and death, or age at death)* }(\%)\end{array}$ & $5.4 \%$ & $7.0 \%$ & $14.0 \%$ \\
\hline $\begin{array}{l}\text { Died during World War II up to the end of the war in } \\
\text { Italy (ie, up to } 29 \text { April 1945) (\%) }\end{array}$ & $\begin{array}{l}23.6 \% \\
(79 / 335)\end{array}$ & NA & NA \\
\hline $\begin{array}{l}\text { 'Killed on active service' (KoAS) after the end of the war } \\
\text { in Italy (\%) }\end{array}$ & $\begin{array}{l}1.2 \% \\
(4 / 335)\end{array}$ & $0.0 \%$ & $0.0 \%$ \\
\hline $\begin{array}{l}\text { Died in the postwar period up to } 31 \text { December } 1949 \text { for } \\
\text { known dates of death (other than KoAS—as above) (\%) }\end{array}$ & $\begin{array}{l}1.6 \% \\
(5 / 317)\end{array}$ & $\begin{array}{l}3.0 \% \\
(4 / 132)\end{array}$ & $\begin{array}{l}0.7 \% \\
(1 / 147)\end{array}$ \\
\hline
\end{tabular}

${ }^{*}$ As of mid-2021, all but one member of the 28th (Māori) Battalion were reported to be deceased. 
Table 2 Life span results for the combat-exposed cohort (28th (Māori) battalion) and the two non-combat exposed cohorts (the 15th (Māori) Reinforcements; Māori personnel in Jayforce) of New Zealand military personnel

\begin{tabular}{|c|c|c|c|}
\hline Specific population & Mean age (years) at death (SD) & Median age (years) at death (IQR) & Statistical analyses and comment \\
\hline \multicolumn{4}{|l|}{ By combat exposure } \\
\hline $\begin{array}{l}\text { Combat exposed and killed during the war } \\
\text { up to the end of the war in Italy, for those } \\
\text { with known dates of death }(n=79)\end{array}$ & $\begin{array}{l}27.1 \\
(4.2)\end{array}$ & $\begin{array}{l}25.5 \\
(23.5-30.5)\end{array}$ & $\begin{array}{l}\text { This is a loss per individual of } 39.6 \text { years of life } \\
\text { compared with veterans from this Battalion who } \\
\text { survived }(66.7-27.1=39.6) \text {. See online supplemental } \\
\text { file 1) for additional details on the specific causes } \\
\text { of death. }\end{array}$ \\
\hline
\end{tabular}

\begin{tabular}{|c|c|c|c|}
\hline $\begin{array}{l}\text { Combat exposed (all personnel): full random } \\
10 \% \text { sample of the 28th (Māori) Battalion } \\
\text { for whom age at death could be determined } \\
(n=317)\end{array}$ & $\begin{array}{l}56.3 \\
(21.0)\end{array}$ & $\begin{array}{l}61.0 \\
(33.5-73.5)\end{array}$ & \\
\hline $\begin{array}{l}\text { Combat exposed veterans: as above but } \\
\text { for just veterans who survived the war and } \\
\text { who were not subsequently killed on active } \\
\text { service (KoAS, } n=234)\end{array}$ & $\begin{array}{l}66.7 \\
(13.4)\end{array}$ & $\begin{array}{l}67.1 \\
(59.1-77.1)\end{array}$ & $\begin{array}{l}\text { There was no statistically significant difference } \\
\text { between these three groups ( } p=0.9368 \text {, ANOVA) } \\
\text { or between the combat exposed and the two non- } \\
\text { combat groups combined ( } p=0.7475 \text {, ANOVA) }\end{array}$ \\
\hline $\begin{array}{l}\text { Non-combat exposed (15th): the 15th } \\
\text { Reinforcements of the } 28 \text { th (Māori) } \\
\text { Battalion for whom age at death could be } \\
\text { determined ( } n=132 \text { ) }\end{array}$ & $\begin{array}{l}67.2 \\
(13.9)\end{array}$ & $\begin{array}{l}67.3 \\
(59.4-76.8)\end{array}$ & \\
\hline $\begin{array}{l}\text { Non-combat exposed Māori personnel in } \\
\text { Jayforce (those with no other participation } \\
\text { in any other war) ( } n=147)\end{array}$ & $\begin{array}{l}66.9 \\
(15.4)\end{array}$ & $\begin{array}{l}68.6 \\
(60.5-77.1)\end{array}$ & \\
\hline \multicolumn{4}{|c|}{ By other characteristics - random sample of the 28th (Māori) Battalion with life span data } \\
\hline Had any name in te reo Māori $(n=245)$ & $\begin{array}{l}55.9 \\
(20.6)\end{array}$ & $\begin{array}{l}60.5 \\
(33.5-73.2)\end{array}$ & $\begin{array}{l}\text { There was no statistically significant difference } \\
\text { between these two groups ( } p=0.5055 \text {, ANOVA) }\end{array}$ \\
\hline No te reo Māori name $(n=72)$ & $\begin{array}{l}57.7 \\
(22.5)\end{array}$ & $\begin{array}{l}64.6 \\
(30.5-75.6)\end{array}$ & \\
\hline Military rank was private/trooper $(n=272)$ & $\begin{array}{l}56.2 \\
(20.8)\end{array}$ & $\begin{array}{l}60.5 \\
(34.0-72.8)\end{array}$ & $\begin{array}{l}\text { There was no statistically significant difference } \\
\text { between these two groups ( } p=0.9776 \text {, ANOVA) }\end{array}$ \\
\hline Officer $(n=62)$ & $\begin{array}{l}56.3 \\
(21.9)\end{array}$ & $\begin{array}{l}64.3 \\
(33.1-77.0)\end{array}$ & \\
\hline
\end{tabular}

ANOVA, analysis of variance.

\section{RESULTS}

Notable differences were present between the compared cohorts (Table 1). In particular, their median birth years differed, that is, 1918 for the 28th (Māori) Battalion, 1923 for the 15th Reinforcements and 1926 for the Jayforce only group. Inability to determine an age at death also varied: $5.4 \%, 7.0 \%$ and $14.0 \%$, respectively.

When comparing the average life spans of combat and noncombat soldiers, there was no statistically significant reduction for the veterans of the 28th (Māori) Battalion (66.7 years) relative to those of the two non-combat cohorts: the 15th Reinforcements (67.2 years) and the Māori personnel in Jayforce (66.9 years) (Table 2). When just considering the 28th (Māori) Battalion, there were no meaningful differences in life span by the soldiers' names (in te reo Māori (language) or not), and by their military rank.

\section{DISCUSSION}

\section{Main findings}

When comparing the veteran groups, there was no statistically significant reduction in the average life span of the combatexposed 28th (Māori) Battalion veterans (66.7 years), relative to those of two non-combat exposed cohorts: the 15th Reinforcements (67.2 years), and the Māori personnel in Jayforce (66.9 years). These findings were perhaps surprising, given the high level of wounding in the 28th (Māori) Battalion, estimated at $48 \%$ of personnel. ${ }^{10}$ Similarly, some were also exposed to the hardships of being POWs (Table 1).
Indeed, these findings contrast with evidence that participation in WW1 was associated with a reduced life span of New Zealand veterans relative to that for a comparable non-combat group of military personnel (Table 3$).{ }^{14}$ Similarly for another New Zealand study, which also reported reduced life span for a WW2 cohort, although this study used a national comparison group. ${ }^{15}$ Adverse morbidity impacts for New Zealand WW2 veterans have also been reported from survey data, ${ }^{16}$ psychiatric studies, ${ }^{17}$ a study of war pensions ${ }^{18}$ and from interviews with veterans. ${ }^{19}$ The large scale of these morbidity impacts was also suggested by the 22846 WW2 New Zealand personnel receiving war pensions in 1946 for service-related disabilities. ${ }^{20}$ By 1985 , more than 10000 of these veterans were officially recognised as suffering from 'nervous system disabilities', with cases of posttraumatic stress disorder (PTSD) and alcohol misuse. ${ }^{19}{ }^{[\mathrm{p} 14]}$ A more contemporary study of New Zealand military personnel published in $2020,{ }^{21}$ reported that $10 \%$ of participants had symptoms indicative of a clinical diagnosis of PTSD. It also reported that risk factors for PTSD were: trauma exposure, older age, male sex and Māori ethnicity.

Furthermore, we would have expected the non-combat cohorts to have slightly longer life spans anyway, given their later median birth years (Table 1). This is because of the ongoing trends in improving life expectancy in the twentieth century for New Zealand men. For example, the average life expectancy for 27-year-old New Zealand men born in 1916 and 1926 has been estimated at 45.2 years and 48.1 years, respectively (ie, an increase in life expectancy of 2.4 months per year over 
Table 3 Comparison of the results for this study with the life span results for other studies involving New Zealand military personnel in three wars

Particular war and group of New Zealand military personnel involved

\begin{tabular}{|c|c|c|}
\hline South African War: random sample of combat personnel, excluding those who participated in any other wars $(n=120)^{25}$ & 68.5 & 72.4 \\
\hline $\begin{array}{l}\text { South African War: random sample of non-combat exposed personnel who arrived in the war zone just before it ended } \\
(n=74)^{25}\end{array}$ & 69.1 & 70.3 \\
\hline WW1: random sample of military personnel who enlisted in 1914 and were exposed to combat $(n=350)^{14}$ & Not calculated & 65.9 \\
\hline WW1: veterans of the combat exposed group (in the row directly above) who survived the war $(n=214)^{14}$ & Not calculated & 72.6 \\
\hline WW1: random sample of military personnel who enlisted in 1918 and were non-combat exposed $(n=330)^{14}$ & Not calculated & 74.2 \\
\hline $\begin{array}{l}\text { WW2: random sample of 28th (Māori) Battalion personnel (this study)_including those who died in the war and those who } \\
\text { survived ( } n=317 \text { ) }\end{array}$ & 56.3 & 61.0 \\
\hline WW2: 28th (Māori) Battalion veterans who were exposed to combat and survived the war (this study) $(n=234)$ & 66.7 & 67.1 \\
\hline WW2: 15th Reinforcements of the 28th (Māori) Battalion that were non-combat exposed (this study) ( $n=132)$ & 67.2 & 67.3 \\
\hline WW2: Māori personnel in Jayforce that were non-combat exposed (this study) ( $n=147$ ) & 66.9 & 68.6 \\
\hline $\begin{array}{l}\text { WW2: study of veterans who survived WW2 and were buried in a single large NZ cemetery (and who were not veterans of } \\
\text { other wars) }(n=720)^{15}\end{array}$ & 68.5 & 68.0 \\
\hline
\end{tabular}

WW1, World War I; WW2, World War II.

this 10-year period; using Statistics New Zealand life tables for Māori and non-Māori men combined). ${ }^{22}$

Nevertheless, a possible reason for the lack of veteran life span differences is that veterans in the combat exposed cohorts may have had relatively higher status in their communities (relative to non-combat veterans) which might have contributed to additional employment benefits and psychological health benefits. Indeed, the returning members of the 28th (Māori) Battalion appear to have been particularly highly respected by their communities. ${ }^{7-9}$ Furthermore, it was reported that personnel in the Māori Battalion in WW2 had a morale that 'was so high that there was a consequent reduction in anxiety neurosis'; and that they had much lower incidences of 'neurosis' and 'neurasthenia' (terms potentially overlapping with PTSD) than non-Māori personnel. ${ }^{23}$

Comparisons with New Zealand participants in other wars (Table 3), suggest that the life span of 28th (Māori) Battalion participants and veterans was lower than that for personnel participating in the South African War, WW1 and WW2 in general. This is likely to again reflect the 28th Battalion being an infantry battalion with extensive front-line action (see Introduction), but also the lower life span for all Māori in comparison to non-Māori in the period. ${ }^{24}$

\section{Study strengths and limitations}

This study is the most detailed to date of mortality risk and life span of New Zealand military personnel arising from participation in WW2 (to our knowledge). It benefited from the natural experiment of there being relatively comparable groups (combat vs non-combat exposed) which had been through a similar selection process into the military (ie, avoiding the 'healthy soldier effect'). ${ }^{4}$

Nevertheless, there are various limitations with this study. In particular, the groups were not fully comparable, as shown in Table 1 (eg, some modest differences in median birth dates and the level of ascertainment of age at death). Other grouplevel differences of possible relevance (but for which we did not have data) included health status on selection into the military (including height and weight), and smoking status. Also, postwar experiences by group may have differed in terms of access to employment, and further training/education, with these potentially impacting on life span. Other limitations included:

- The sample sizes were not particularly large; although as this was an unfunded study, that was largely unavoidable.
- For where the data were not in the official records, we occasionally had to use data added by family members to the Cenotaph database or the 28th (Māori) Battalion role (eg, date of death or age at death). Such data could potentially be less accurate than official records.

- For some records, there was also imprecision in the age at death calculated, due to there being just birth year or an age of death that was rounded to a year.

\section{Potential implications for further research}

Given the importance of the legacy of major wars on society, this type of study could be expanded if it was possible to fund genealogical researchers to conduct work with larger samples. This would then allow, for example, the life span implications of POW status to be explored and comparison samples out of all WW2 participants. Obtaining all the death certificates (although still relatively expensive in the New Zealand setting), would also allow exploration of the cause of death among veterans (eg, if likely to be war-related or not, and the potential role of trends in smoking-related disease such as from lung cancer). It would be important to have Māori historians involved to better understand the important social and cultural dimensions around how veterans were treated by their own communities and by wider New Zealand society. To ensure this research is done, and given its relevance to veteran health issues, it would ideally be funded by Veterans' Affairs New Zealand or the New Zealand Defence Force. Alternatively, the Ministry of Culture and Heritage could support work in this major domain of New Zealand's history.

\section{CONCLUSIONS}

Despite a very high level of wounding in the combat-exposed group (48\%), there were no statistically significant reductions in life span between this group and comparable non-combat exposed veterans. This finding contrasts to life span reductions found in a similar study of New Zealand veterans of WW1.

Contributors NW conceived the idea and managed the project. CC and NW gathered and processed the appropriate data. NW conducted the analyses and wrote the first draft. All authors contributed to interpretation and revising multiple drafts of the manuscript.

Funding The authors have not declared a specific grant for this research from any funding agency in the public, commercial or not-for-profit sectors.

Competing interests None declared.

Patient consent for publication Not applicable. 
Ethics approval Ethical approval was provided by the University of Otago Human Ethics Committee (Category B Approval, reference number D21/247).

Provenance and peer review Not commissioned; externally peer reviewed. Data availability statement Data are available upon reasonable request.

Supplemental material This content has been supplied by the author(s). It has not been vetted by BMJ Publishing Group Limited (BMJ) and may not have been peer-reviewed. Any opinions or recommendations discussed are solely those of the author(s) and are not endorsed by BMJ. BMJ disclaims all liability and responsibility arising from any reliance placed on the content. Where the content includes any translated material, BMJ does not warrant the accuracy and reliability of the translations (including but not limited to local regulations, clinical guidelines, terminology, drug names and drug dosages), and is not responsible for any error and/or omissions arising from translation and adaptation or otherwise.

ORCID iD

Nick Wilson http://orcid.org/0000-0002-5118-0676

\section{REFERENCES}

1 Elder GH, Clipp EC, Brown JS, et al. The life-long mortality risks of World War II experiences. Res Aging 2009;31:391-412.

2 Keehn RJ. Follow-up studies of World War II and Korean conflict prisoners. III. mortality to January 1, 1976. Am J Epidemiol 1980;111:194-211.

3 Guest CS, Venn AJ. Mortality of former prisoners of war and other Australian veterans. Med J Aust 1992;157:132-5.

4 McLaughlin R, Nielsen L, Waller M. An evaluation of the effect of military service on mortality: quantifying the healthy soldier effect. Ann Epidemiol 2008;18:928-36.

5 New Zealand Government. Second New Zealand Expeditionary force. nominal roll second New Zealand Expeditionary force No. 16 (Embarkations from 1st January, 1946 to 30th June, 1948). Wellington, Government Printer, 1950

6 History Group Ministry for Culture and Heritage. Story of the 28th: About the 28th. History Group, Ministry for Culture \& Heritage. Available: https://28maoribattalion. org.nz/story-of-the-28th

7 Gardiner W. Te mura o te ahi: the story of the Maori Battalion. Auckland: Reed Books, 1992.

8 Soutar M. Nga Tama Toa - The Price of Citizenship - C Company 28 (Maori) Battalion 1939-1945. Auckland: David Bateman, 2008.
9 Gardiner W. Ake Ake Kia Kaha E! forever brave! B Company 28 (Maori) Battalion 1939-1945. Auckland: David Bateman, 2019.

10 Ministry for Culture and Heritage. 28th Maori Battalion: battalion roll. Available: https://28maoribattalion.org.nz/roll [Accessed Jul 2020].

11 Ministry for Culture and Heritage. 28th Maori Battalion: soldiers of the 15th Reinforcements, Jayforce and other units. Available: https://28maoribattalion.org.nz/ node/3775 [Accessed Jul 2020].

12 Department of Internal Affairs. Births, Deaths \& Marriages Online. Available: https:// www.bdmhistoricalrecords.dia.govt.nz/search/

13 Auckland War Memorial Museum. Cenotaph database. Available: https://www. aucklandmuseum.com/war-memorial/online-cenotaph [Accessed Jul 2020].

14 Wilson N, Clement C, Summers JA, et al. Mortality of First World War military personnel: comparison of two military cohorts. BMJ 2014;349:g7168.

15 Wilson N, Harper G. Lifespan of New Zealand Second World War veterans from one large cemetery: the case for a national-level study. N Z Med J 2019;132:96-8.

16 Salmond GL, Salmond CE. The health of former servicemen. New Zealand, war pensions medical research trust board, 1977.

17 Macleod AD. Psychiatric casualties of World War II. N Z Med J 2000;113:248-50.

18 Jenks T, Wanhalla A. Psychological casualties: war neurosis, rehabilitation, and the family in Post-World War II New Zealand. Health History 2020;22:1-25.

19 Parr A. Silent Casualties: New Zealand's Unspoken Legacy of the Second World War. Auckland: Tandem Press, 1995

20 Statistics New Zealand. The New Zealand official year-book, 1946. Available: https:// www3.stats.govt.nz/New_Zealand_Official_Yearbooks/1946/NZOYB_1946.html?_ $\mathrm{ga}=2.1094705 .1255873467 .1547827122-1031987571.1539970965 \# i d s e c t 1 \_1$ 310990

21 Richardson A, Gurung G, Samaranayaka A, et al. Risk and protective factors for posttraumatic stress among New Zealand military personnel: a cross sectional study. PLoS One 2020;15:e0231460.

22 Statistics New Zealand. A history of survival in New Zealand: cohort life tables 1876-2004. Wellington: Statistics New Zealand, 2006. https://statsnz.contentdm. oclc.org/digital/collection/p20045coll1/id/663/

23 Stout T, Duncan M. Chapter 23: health of Maoris in 2 NZEF. In: War surgery and medicine. Wellington: New Zealand, 1954. http://www.nzetc.org/tm/scholarly/teiWH2Surg-pt2-c23.html\#n734

24 Woodward A, Blakely T. The healthy country? a history of life and death in New Zealand. Auckland: Auckland University Press, 2014.

25 Wilson N, Clement C, Thomson G, et al. Health impacts for New Zealand military personnel from the South African war of 1899-1902. N Z Med J 2021:134:22-43. 
Impact of war on veteran life span; natural experiment involving combat versus non-combat expose military personnel

\author{
Wilson, $\mathrm{N}$
}

$2021-12-22$ 